\title{
Assessment of Cervical Length by Transvaginal Ultrasound in Pregnant Women Between 24-34 Weeks
}

\author{
Gebelerde Transvajinal Ultrason ile 24-34 Hafta Arasında Servikal Uzunluğun \\ Değerlendirilmesi
}

\author{
(D) Salim Sezer1, (D) Alpaslan Kaban², (D) Baki Erdem¹ \\ 1 University of Health Sciences, Kanuni Training and Research Hospital, Clinic of Gynecology and Obstetrics, Trabzon, Turkey \\ 2istanbul Training and Research Hospital, Clinic of Gynecology and Obstetrics, İstanbul, Turkey
}

\begin{abstract}
Introduction: The purpose of this study was to assess the role of cervical length measurement by transvaginal ultrasound for predicting preterm delivery.

Methods: Cervical lengths were measured by transvaginal ultrasound in 73 pregnant women with 24-34 weeks of gestation. Cervical length measurements were analyzed for the predictability of preterm birth.

Results: Of the 73 pregnant women, 19 (26\%) had preterm labor (<37 weeks) and 54 (74\%) had term labor. For predicting preterm birth, cut-off values were determined using the Receive Operating Characteristic Curve curves and corresponding values. The cut-off value of the cervical length was 31.5 millimeters and sensitivity, specificity, positive predictive value and negative predictive value were $70.3 \%, 89.4 \%, 51.5 \%$ and $95 \%$, respectively.

Conclusion: According to the study, the evaluation of cervical length by transvaginal ultrasound in pregnant women with 24-34 weeks of gestation may be useful as a screening test for preterm birth prediction. The risk of premature birth in pregnant women with a cervical length more than $31 \mathrm{~mm}$ is minimal.
\end{abstract}

Keywords: Cervical length, preterm birth, transvaginal ultrasound

\section{öz}

Amaç: Bu çalıșmanın amacı, erken doğumu öngörmede transvajinal ultrason ile servikal uzunluk ölçümünün rolünü değerlendirmektir.

Yöntemler: Yirmi dört-otuz dört haftalık gebeliği olan 73 kadında, transvajinal ultrasonografi ile servikal uzunluklar ölçüldü. Servikal uzunluk ölçümleri preterm doğum tahmin edilebilirliği açısından analiz edildi.

Bulgular: Yetmiş üç gebe kadından 19'u preterm (<37 hafta) (\%26) ve 54'ü (\%74) miadında doğum yaptı. Erken doğumu kestirmek için, kesme değerleri Receive Operating Characteristic Curve eğrileri ve karşılık gelen değerler kullanılarak belirlendi. Servikal uzunluğun kesme değeri 31,5 milimetre olarak belirlendi ve duyarlılı, özgüllük, pozitif prediktif değer ve negatif öngörü değeri sırasıyla $\% 70,3, \% 89,4, \% 51,5$ ve $\% 95$ idi.

Sonuç: Çalışmaya göre, gebe kadınlarda 24-34. haftalar arasında transvajinal ultrasonografi ile servikal uzunluğun değerlendirilmesi preterm doğum tahmini için tarama testi olarak faydalı olabilir. 31 mm'nin üzerinde servikal uzunluğa sahip gebelerin prematür doğum riski minimaldir.

Anahtar Kelimeler: Servikal uzunluk, erken doğum tahmini, transvajinal ultrason

\section{Introduction}

Preterm delivery is the birth that occurred before the completion of 37 weeks of gestation. The rate of preterm birth is different in reports and can be up to $15 \%$ (1-4). According to the literature, the incidence of preterm delivery has increased in recent years (5). Preterm delivery is one of the main causes of neonatal morbidity and mortality (5). The risk of mortality and serious acute morbidities such as respiratory distress syndrome, necrotizing enterocolitis and intraventricular hemorrhage are related with preterm birth $(6,7)$.

In recent years, cervical length measurement by cervical transvaginal ultrasound (US) has been proposed as an effective method for predicting preterm delivery (8-11). However, there is no consensus on the routine use of cervical length measurement for predicting preterm delivery (1214).
Address for Correspondence/Yazıșma Adresi: Alpaslan Kaban, İstanbul Training and Research Hospital, Clinic of Gynecology and Obstetrics, İstanbul, Turkey

Phone: +90 5322609684 E-mail: alpaslankaban@gmail.com ORCID ID: orcid.org/0000-0002-3623-7240

Cite this article as/Atıf: Sezer S, Kaban A, Erdem B. Assessment of Cervical Length by Transvaginal Ultrasound in Pregnant Women Between 24-34 Weeks. İstanbul Med J 2019; 20(2): 98-100.

(c) Copyright 2019 by the Istanbul Training and Research Hospital/Istanbul Medical Journal published by Galenos Publishing House.

(C) Telif Hakkı 2019 Istanbul Ĕgitim ve Araștırma Hastanesi/Istanbul Tıp Dergisi, Galenos Yayınevi tarafından basılmıștır.
Received/Gelis Tarihi: 18.05.2018 Accepted/Kabul Tarihi: 06.12.2018 
In this study, the relationship between cervical length measurement by transvaginal US and preterm delivery was investigated.

\section{Methods}

This study was performed in pregnant women between 24-34 weeks of pregnancy who applied to the obstetrics clinic for routine antenatal follow-up. İstanbul Gaziosmanpașa Taksim Training and Research Local Ethics Committee approval was obtained for this study (decision number: 16.01.2009). Informed consent form was obtained from all patients included in the study. Patients with vaginal bleeding, membranous rupture, pregnancies with $>3 \mathrm{~cm}$ of cervical dilatation, mandatory birth due to fetal or maternal reasons were excluded. Pregnancy history was obtained, the last menstrual period (LMP) was recorded and gestational week was calculated. Gestational weeks were calculated according to the first trimester US of pregnant women who did not know the LMP. The first trimester US was used to determine gestational week if there was a significant difference (more than 7days) between the LMP and first trimester US. The pregnancies that did not have first trimester US and did not know LMP were not included in the study.

The vaginal US probe was prepared by attaching a condom to the tip. The cervix was assessed by transvaginal US. Cervical length measurement was performed visualizing the cervical internal ostium, external ostium and cervical channel on the same line.

A total of 80 pregnant women were included in the study. After the study was completed, seven pregnant women were excluded from the study due to missing data.

Those who gave birth at $\geq 37$ gestational weeks were accepted as term delivery and $<37$ gestational weeks as preterm delivery.

\section{Statistical Analysis}

Statistical analysis was performed by SPSS. Mann-Whitney U test was used in the comparisons between independent groups. The chi-square test was used to compare expected and observed values.

\section{Results}

Of 73 pregnant women, 19 had preterm and 54 had term delivery. The results of these two groups were compared. There was no significant difference between the two groups regarding median gestational age at the time of examination ( $p=0.477$ ). The mean birth age was $242 \pm 11$ days in preterm delivery and $275 \pm 7$ days in term delivery. The mean birth weight was $2371 \pm 292$ grams at preterm delivery and $3302 \pm 430$ grams at term delivery and the difference was statistically significant $(p<0.001)$ (Table 1).

\section{Cervical Length}

The cut-off value of the cervical length was determined using the Receive Operating Characteristic (ROC) curve and the corresponding cervical length values, and the cut-off value was determined as $31.5 \mathrm{~mm}$. The sensitivity, specificity, positive predictive value, negative predictive value and accuracy rate were $70.3 \%, 89.4 \%, 51.5 \%, 95 \%$ and $75.3 \%$, respectively (Table 2, Figure 1). Cervical length in 17 of 19 pregnant women who underwent preterm delivery was below the cut-off value of $31.5 \mathrm{~mm}$ (89.4\%).

\section{Discussion}

The World Health Organization recognizes births that occur before the completion of 37 gestational weeks as premature births (4). Preterm delivery is a major cause of morbidity and mortality (15). Cervical length measurement by cervical transvaginal US is suggested as an effective screening method for premature birth $(8,9,16)$. However, some studies suggest that it is not useful as a screening method $(12,13)$.

The cervical length can be measured in different ways by US. These are transabdominal, transperineal and transvaginal approaches. Transvaginal approach is considered to be the gold standard (17). In our study, cervical lengths were measured by transvaginal US in 73 women. The cervical length was shorter in women who gave birth before 37 weeks (defined as preterm labor) $(24 \pm 7 \mathrm{~mm}$ vs $34 \pm 7 \mathrm{~mm}, \mathrm{p}<0.001)$

\begin{tabular}{|l|l|l|l|}
\hline \multicolumn{3}{|l|}{ Table 1. Characteristics of preterm and term groups } \\
\hline Features & $\begin{array}{l}\text { Preterm } \\
(\mathbf{n = 1 9 )}\end{array}$ & $\begin{array}{l}\text { Term } \\
(\mathbf{n = 5 4 )}\end{array}$ & $\mathbf{p}$ \\
\hline Cervical length, (mm) mean \pm SD & $24 \pm 7$ & $34 \pm 7$ & $<0.001$ \\
\hline $\begin{array}{l}\text { Gestational age during } \\
\text { examination, median (95\% Cl) }\end{array}$ & $32(30-33)$ & $32(28-33)$ & 0.477 \\
\hline Age of birth, (days) mean \pm SD & $242 \pm 11$ & $275 \pm 7$ & $<0.001$ \\
\hline Birth weight, (gr) mean \pm SD & $2371 \pm 292$ & $3302 \pm 430$ & $<0.001$ \\
\hline Cl: confidence interval, SD: standard deviation & & \\
\hline
\end{tabular}

Table 2. Predictive values of cervical length with a cut-off value of $31.5 \mathrm{~mm}$

\begin{tabular}{|l|l|l|l|}
\hline & $\begin{array}{l}\text { Preterm } \\
(\mathbf{n = 1 9})\end{array}$ & Term $(\mathbf{n = 5 4 )}$ & Total \\
\hline Cervical length $(\leq 31.5 \mathrm{~mm})$ & $51.5 \%(17)$ & $48.5 \%(16)$ & 33 \\
\hline Cervical length $(>31.5 \mathrm{~mm})$ & $5.0 \%(2)$ & $95.0 \%(38)$ & 40 \\
\hline Total & 19 & 54 & 73 \\
\hline
\end{tabular}

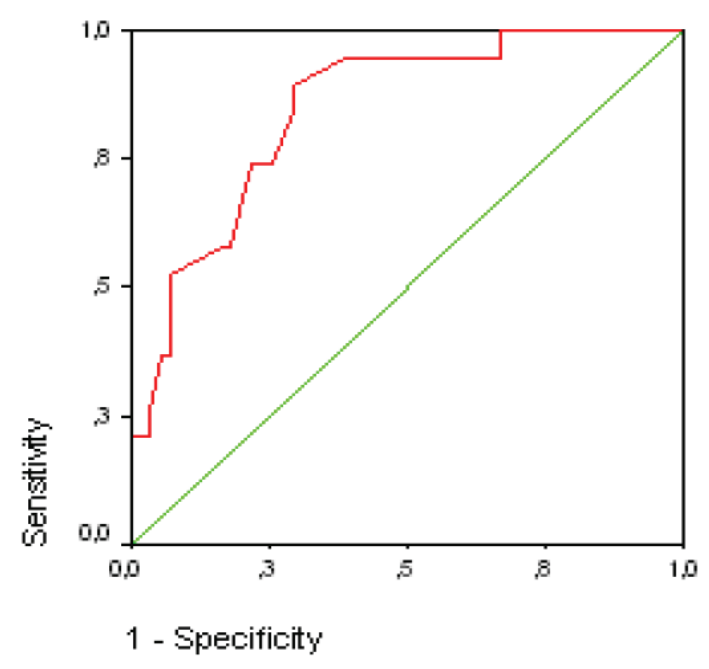

Figure 1. Receive Operating Characteristic Curve of cervical length (the area under the Receive Operating Characteristic Curve is 0.85) 
When the cut-off value was accepted as $31.5 \mathrm{~mm}$, the negative predictive value was $95 \%$. Of the 40 women whose cervical length measurements were above the cut-off value, only 2 had preterm labor (Table 2). The risk of preterm delivery was $51.5 \%$ if the cervical length was shorter than $31 \mathrm{~mm}$.

According to Timothy and colleagues, $25 \mathrm{~mm}$ cervical length has the best predictive accuracy (8). If the cervical length is shortened and it is detected early in pregnancy, the risk of preterm birth increases.

According to the studies of Kuusela et al. (14), there was no significant association between cervical length $(<25 \mathrm{~mm})$ and spontaneous preterm delivery at $<37$ weeks. The authors reported a significant relationship between cervical length and spontaneous preterm birth at $<34$ weeks and reported that a larger study is needed to evaluate the prevalence of short cervical length and the possible association with preterm delivery before universal screening is recommended.

There are three main mechanisms associated with the development of a short cervical length (18). Firstly, the most accepted hypothesis is that of an internal weakness of a short cervical length. This cervical insufficiency is usually caused by traumatic or surgical injury or, more rarely, by a congenital disorder or connective tissue disease. Second, another hypothesis is that a short cervical length is due to an inflammatory or infectious process. In the other hypothesis, it is thought that shortening of cervical length is due to uterine contractions. Studies have shown that asymptomatic women with a cervical length less than $25 \mathrm{~mm}$ before 24 weeks have higher risk of preterm birth more than controls with a normal cervix (9).

\section{Conclusion}

This study showed that measurement of cervical length by transvaginal US might be useful as a screening test in predicting preterm birth. In this study, the cut-off value was found to be $31.5 \mathrm{~mm}$ and the probability of premature birth was lower in women with a cervical length above this value.

Ethics Committee Approval: İstanbul Gaziosmanpaşa Taksim Training and Research Local Ethics Committee approval was obtained for this study (decision number:16.01.2009).

Informed Consent: Informed consent form was obtained from all patients included in the study.

Peer-review: Externally peer-reviewed.

Author Contributions: Concept - S.S.; Design - S.S., A.K., B.E.; Supervision - A.K.; Resources - S.S., A.K.; Materials - S.S.; Data Collection and/or Processing - S.S., A.K.; Analysis and/or Interpretation - A.A.; Literature Search - S.S., A.K.; Writing Manuscript - S.S., A.K.; Critical Review - S.S., A.K., B.E.
Conflict of Interest: No conflict of interest was declared by the authors.

Financial Disclosure: The authors declared that this study received no financial support.

\section{References}

1. Goldenberg RL, Culhane JF, lams JD, Romero R. Epidemiology and causes of preterm birth. Vol. 371, The Lancet. 2008. p. 75-84.

2. Slattery MM, Morrison JJ. Preterm delivery. Vol. 360, Lancet. 2002. p. 1489-97.

3. Simhan HN, Caritis SN. Prevention of preterm delivery. N Engl J Med. 2007; 357: 477-87.

4. Spong CY. Defining "term" pregnancy: Recommendations from the defining "term" pregnancy workgroup. Vol. 68, Obstetrical and Gynecological Survey. 2013. p. $611-2$.

5. Slattery MM, Morrison JJ. Preterm delivery. Lancet 2015; 360: 1489-97.

6. lams JD. Care for women with prior preterm birth. In: Preterm birth: Prevention and Management 2010. p. 115-29.

7. Hodgson EJ, Lockwood CJ. Preterm birth: Prevention and Management-Google Books. Preterm Birth Prev 2010.

8. Rafael TJ. Short Cervical Length. In: Preterm birth: Prevention and Management. 2010. p. 130-48.

9. Mella MT, Berghella V. Prediction of Preterm Birth: Cervical Sonography. Vol. 33, Seminars in Perinatology. 2009. p. 317-24.

10. Gynecologists AC of $\mathrm{O}$ and. Prediction and prevention of preterm birth. Obstet Gynecol 2012; 120: 964-73.

11. Grimes-Dennis J, Berghella V. Cervical length and prediction of preterm delivery. Vol. 19, Current Opinion in obstetrics and gynecology 2007. p. 191-5.

12. Esplin MS, Elovitz MA, lams JD, Parker CB, Wapner RJ, Grobman WA, et al. Predictive accuracy of serial transvaginal cervical lengths and quantitative vaginal fetal fibronectin levels for spontaneous preterm birth among nulliparous women. JAMA-J Am Med Assoc 2017; 317: 1047-56.

13. Conde-Agudelo A, Romero R, Hassan SS, Yeo L. Transvaginal sonographic cervical length for the prediction of spontaneous preterm birth in twin pregnancies: A systematic review and metaanalysis. Am J Obstet Gynecol 2010; 203: 128.e1-12.

14. Kuusela P, Jacobsson B, Söderlund M, Bejlum C, Almström E, Ladfors L, et al. Transvaginal sonographic evaluation of cervical length in the second trimester of asymptomatic singleton pregnancies, and the risk of preterm delivery. Acta Obstet Gynecol Scand 2015; 94: 598-607.

15. Ananth CV, Joseph KS, Oyelese Y, Vintzileos AM. Trends in preterm birth and perinatal mortality among singletons: united states, 1989 through 2000 Obstet Gynecol 2005; 105: 1084-91.

16. Ginsberg Y, Goldstein I, Khatib N, Farago N, Weiner Z. Lower uterine segment thickness and cervical length. Volume 212, Issue 1, Supplement, Page S134. DOI: https://doi.org/10.1016/j.ajog.2014.10.290

17. O'Hara S, Zelesco M, Sun Z. Cervical length for predicting preterm birth and a comparison of ultrasonic measurement techniques. Australas J Ultrasound Med 2013; 16: 124-34.

18. Callen P. Ultrasonography in obstetrics and gynaecology. $5^{\text {th }}$ ed. Philadelphia: Saunders Elsevier; 2008. 